\title{
Differences in the susceptibility of some penaeid prawn species to gill-associated virus (GAV) infection
}

\author{
Kirsten M. Spann*, R. Alan Donaldson, Jeff A. Cowley, Peter J. Walker \\ Co-operative Research Centre for Aquaculture, CSIRO Tropical Agriculture, PB 3, Indooroopilly 4068, Queensland, Australia
}

\begin{abstract}
Four species of penaeid prawn cultured in Australia (Penaeus monodon, Penaeus esculentus, Marsupenaeus japonicus and Fenneropenaeus merguiensis) were injected with a virulent preparation of gill-associated virus (GAV). $P$. monodon (average weight $=8.9,13.9$ and $19.2 \mathrm{~g}$ ), $P$. esculentus (average weight $=19.5 \mathrm{~g}$ ), $F$. merguiensis (average weight $=10.5 \mathrm{~g}$ ), and small (average weight $=5.8 \mathrm{~g}$ ) $M$. japonicus displayed overt signs of disease and mortalities which reached 82 to $100 \%$ within 23 d post-injection. Cumulative mortalities in $P$. esculentus and F. merguiensis were significantly lower than for $P$. monodon of the same size class. Medium (average weight $=13.0 \mathrm{~g})$ $M$. japonicus also developed overt signs of disease but cumulative mortalities were not significantly higher than uninfected controls. Large (average weight = 20.3 g) $M$. japoncius did not display symptoms of disease and there were no significant mortalities up to $23 \mathrm{~d}$ post-injection.
\end{abstract}

KEY WORDS: Gill-associated virus, GAV - Penaeid prawn · Disease

Resale or republication not permitted

without written consent of the publisher

Gill-associated virus (GAV) has caused stock losses to the Penaeus monodon culture industry in Australia at least since 1996. Diseased P. monodon infected with GAV display pink to red colouration of the body and appendages, and pink to yellow colouration of the gills. Other signs of disease include lethargy, lack of appetite, secondary fouling and tail rot (Spann et al. 1997). Morphologically, GAV resembles yellow-head virus (YHV) from Thailand (Boonyaratpalin et al. 1993). GAV and YHV virions are rod-shaped, enveloped particles containing helical nucleocapsids that mature by budding at intracytoplasmic membranes (Chantanachookin et al. 1993, Spann et al. 1997). Nucleotide sequence comparisons of the putative polymerase (ORF1b) genes have indicated that GAV and

*E-mail: kirsten.spann@tag.csiro.au
YHV are closely related but distinct viruses and are likely to be classified in the order Nidovirales, possibly in the family Coronaviridae (Cowley et al. 1999, 2000a).

Lymphoid organ virus (LOV) has also been described as a rod-shaped, enveloped RNA virus that is endemic in healthy wild and cultured Penaeus monodon in Queensland (Spann et al. 1995). Screening of broodstock collected in northern Queensland has indicated a prevalence of LOV infection that exceeds $96 \%$ (Cowley et al. 2000b). LOV-infected prawns show no visible symptoms of disease, but lymphoid organs typically contain discrete foci (spheroids) of hypertrophied, infected cells. Spheroids are not typically associated with GAV infection in which there is extensive necrosis of lymphoid organ tissue (Spann et al. 1997). Nucleotide sequence comparison of regions in the putative polymerase genes of multiple GAV and LOV isolates has indicated that they are genetically indistinguishable populations (Cowley et al. 2000b). GAV and LOV can be regarded as the same virus, which causes either overt or covert infections in P. monodon. In this paper the name GAV will be used for both overt and covert states of the infection.

Marsupenaeus ${ }^{1}$ japonicus (also called Penaeus japonicus) is the second most common penaeid species cultured in Australia. Although cultured in areas where $P$. monodon is also farmed, there are no reports of overt or covert GAV infection in $M$. japonicus. Penaeus esculentus and Fenneropenaeus merguiensis (also called Penaeus merguiensis) have also been cultured in Australia without evidence of GAV infection. Indeed, screening of wild and cultured penaeids using the sensitive RT-nested PCR test (Cowley et al. 2000b) has indicated that $P$. monodon is the only known natural host of GAV in Queensland. In this paper, we

\footnotetext{
${ }^{1}$ Genus and species names used in this paper are according
} to the taxonomic revision of Pérez-Fanfante \& Kensley (1997) 
examine the susceptibility of these 4 species of penaeid prawn to experimental GAV infection and disease.

Materials and methods. Preparation of inoculation and experimental infections: A standard extract of GAV-infected prawn tissue was used as an inoculum in all experiments. The inoculum was prepared as described previously (Spann et al. 1997) from prawns collected during an outbreak of disease on a farm in northern Queensland in 1996. A total of 25 sub-adult Penaeus monodon were infected with a filtered extract of GAV. At 5 d post-injection (p.i.), 11 of the 25 prawns remained alive and displayed symptoms associated with overt GAV infection. Two of these prawns were fixed for examination by transmission electron microscopy (TEM) to confirm the presence of GAV. The 9 remaining prawns were used for the preparation of the inoculum.

The cephalothoraces of $9 \mathrm{GAV}$-infected prawns were immersed in 6 volumes of lobster haemolymph medium (LHMi Paterson \& Stewart 1974) following removal of the carapace and calcareous mouth parts. A total of $55.6 \mathrm{~g}$ prawn tissue in LHM was homogenized on ice using an Ultra-turrax tissue grinder (Janke \& Kunkel, Ika-werx, Staufen, Germany). The homogenate was clarified at $1300 \times g$ for $5 \mathrm{~min}$ at $4^{\circ} \mathrm{C}$ and the supernatant further clarified at $18000 \times g$ for $20 \mathrm{~min}$ at $4^{\circ} \mathrm{C}$. Supernatant below the lipid layer was divided into $1.5 \mathrm{ml}$ aliquots, snap frozen and stored at $-70^{\circ} \mathrm{C}$. For all experimental infections, aliquots of the inoculum were thawed rapidly in a $37^{\circ} \mathrm{C}$ water bath, passed through a $0.2 \mu \mathrm{m}$ filter and maintained on ice prior to inoculation. Each experimental prawn was injected with $5 \mu^{\prime-1}$ body weight into the second abdominal segment using a 26-gauge needle.

Source of experimental prawns and experimental conditions: Healthy Penaeus monodon, P. esculentus and Marsupenaeus japonicus were collected from 2 farms in south-eastern Queensland and 1 farm in northern Queensland. Healthy Fenneropenaeus mer- guiensis were captured from the Logan River in southeastern Queensland. On arrival, 3 prawns of each species from each location were dissected and the lymphoid organs examined by light microscopy for existing GAV infection. Prawns were maintained in $100 \mathrm{l}$ circular plastic tanks of sea water at a salinity of 27 ppt and a temperature of $26^{\circ} \mathrm{C}$. They were stocked at a density of 8 prawns tank ${ }^{-1}$ in $60 \mathrm{l}$ of water. Water was partially exchanged and the prawns were fed pelleted food daily.

Host susceptibility to GAV: The susceptibility to GAV of prawns from different penaeid species and different size ranges was tested. The species, size ranges and average sizes are shown in Table 1. Of 32 prawns used in each experiment, 16 were injected with GAV and 16 were injected with LHM. The prawns were monitored daily for overt signs of disease and mortalities recorded.

Results and discussion. GAV-free populations of Penaeus monodon have not yet been identified in Australia. The healthy $P$. monodon used in this study displayed histological characteristics typical of covert GAV (i.e. LOV) infection. Lymphoid organs displayed normal tubule structure and contained spheroids of hypertrophic, infected cells (Spann et al. 1995). By light microscopy, there was no evidence of spheroid formation in $P$. esculentus, Marsupenaeus japonicus or Fenneropenaeus merguiensis used in these experiments. Screening of wild and farmed stocks by RT-PCR has also failed to detect evidence GAV infection in any penaeid species other than P. monodon (J.A.C. and colleagues unpubl. data).

Covertly infected Penaeus monodon of different size classes (Table 1) were tested for susceptibility to disease following super-infection with the virulent GAV standard inoculum. Following experimental infection, P. monodon from all 3 size classes displayed typical gross signs of GAV infection including red colouration of the appendages, tail fan and mouth parts, and yel-

Table 1. Species and size classes of penaeid prawns investigated for susceptibility to disease following intramuscular injection with GAV

\begin{tabular}{|llccc|}
\hline Species & Size class & $\begin{array}{c}\text { Range } \\
(\mathrm{g})\end{array}$ & $\begin{array}{c}\text { Average } \\
(\mathrm{g})\end{array}$ & $\begin{array}{c}\text { Number } \\
\text { of prawns }\end{array}$ \\
\hline Penaeus monodon & Small & $6.0-10.8$ & 8.9 & 32 \\
& Medium & $11.2-16.1$ & 13.9 & 32 \\
& Large & $17.7-20.1$ & 19.2 & 32 \\
Marsupenaeus japonicus & Small & $3.8-7.2$ & 5.8 & 32 \\
& Medium & $12.0-14.1$ & 20.3 & 32 \\
Penaeus esculentus & Large & $18.1-22.8$ & 19.5 & 32 \\
Fenneropenaeus merguiensis & Large & Small-medium & $4.2-17.8$ & 10.5 \\
\hline
\end{tabular}




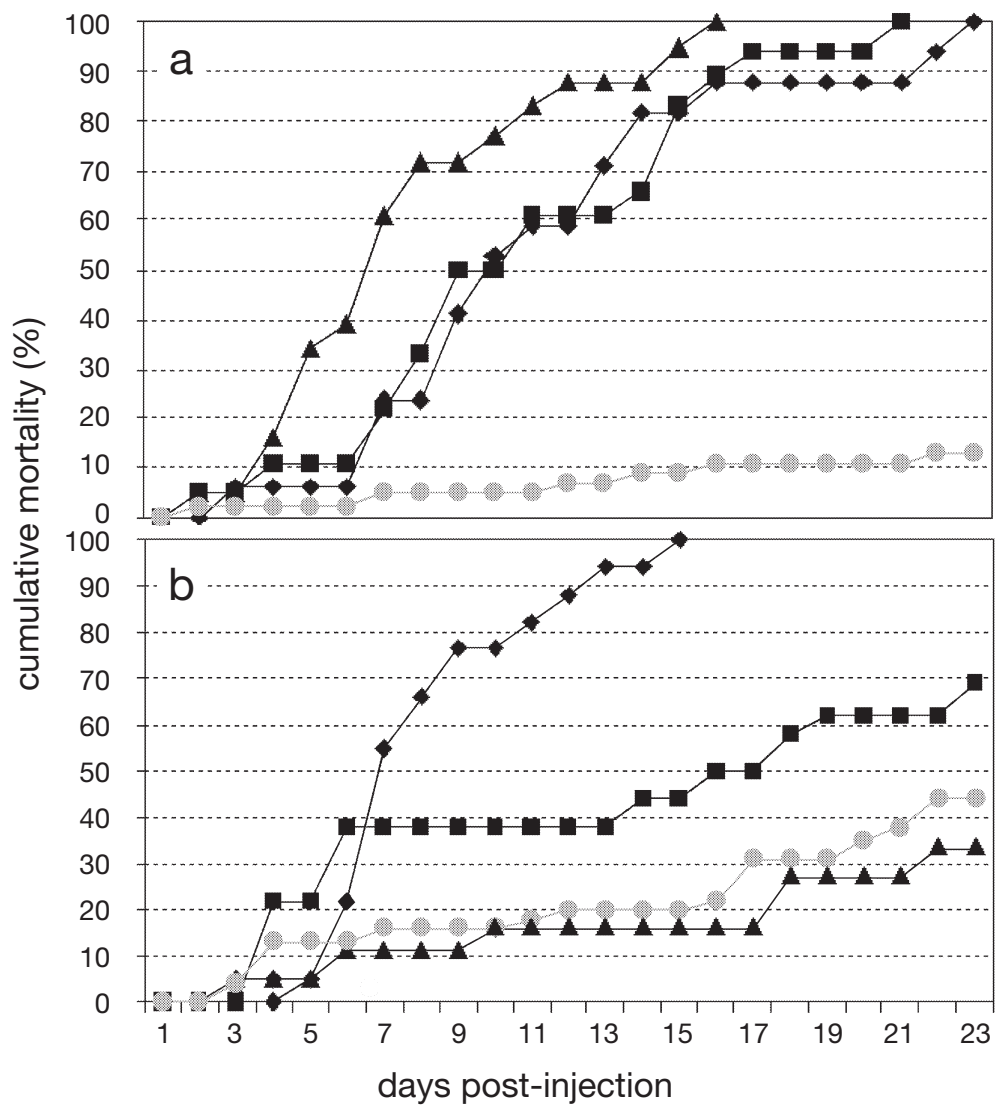

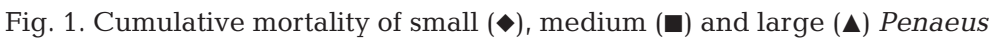
monodon (a) and Marsupenaeus japonicus (b) following injection with a virulent preparation of GAV. Cumulative mortality for negative control prawns from the 3 size classes injected with lobster haemolymph medium (LHM) were pooled $(0)$ for each species
Small M. japonicus also displayed lethargy and a lack of appetite. Large (average weight $=20.3 \mathrm{~g}$ ) experimentally infected $M$. japonicus displayed no gross signs of disease. Significantly different cumulative mortalities were observed between small $M$. japonicus and LHMinjected controls (Fig. 1b; logistic regression coefficient $=-4.5560 ; \mathrm{p}>0.003$, chi-squared test). However, cumulative mortalities for medium and large $M$. japonicus were not significantly different from uninfected controls (logistic regression coefficients were $-0.1133[p>0.925$, chi-squared test] and $-0.4700[p>0.632$; chi-squared test] respectively).

Large healthy Penaeus esculentus (average weight $=19.5 \mathrm{~g}$ ) were also tested for susceptibility to disease following experimental infection with the virulent GAV standard inoculum. Approximately $40 \%$ of infected $P$. esculentus displayed varying degrees of pink to red body, gill and appendage colouration from Day 6 p.i. Lethargy and a lack of appetite were also observed. Cumulative mortalities reached $82 \%$ by Day 10 p.i. (Fig. 2) and occurred at a similar rate to $P$. monodon until Day 14 p.i. However, unlike P. monodon, some $P$. esculentus had survived this dose of GAV at the termination of the experiment on Day 23. The histology of low to pink colouration of the gills (Spann et al. 1997). These symptoms were evident in some prawns from Day 6 p.i. and in all prawns by Day 12 p.i. Lethargy, lack of appetite and tail rot were also commonly observed. Cumulative mortalities for the 3 size classes of $P$. monodon are shown in Fig. 1a. Cumulative mortalities reached $100 \%$ within 16 to $23 \mathrm{~d}$ p.i. for all 3 groups and no size related resistance to disease was observed.

Healthy Marsupenaeus japonicus of different size classes (Table 1) were also tested for susceptibility to disease following experimental infection with the virulent GAV standard inoculum. Following infection, small (average weight $=5.8 \mathrm{~g}$ ) and medium (average weight $=13.0 \mathrm{~g}$ ) M. japonicus displayed abnormal orange body colouration from Day 9 p.i., but the gills remained normal in appearance.

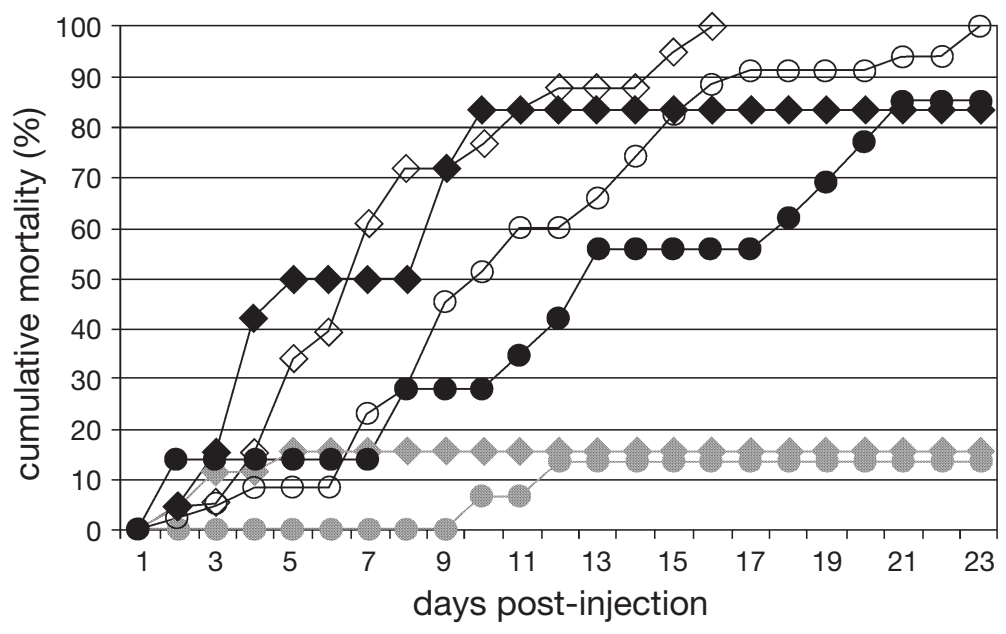

Fig. 2. Cumulative mortality of Penaeus monodon, P. esculentus and Fenneropenaeus merguiensis injected with either a virulent preparation of GAV or LHM. $(\diamond, \diamond)$ P. esculentus injected with GAV and LHM, respectively. $(\bullet, \diamond)$ F. merguiensis injected with GAV and LHM, respectively. ( $\diamond)$ Large $P$. monodon injected with GAV. (O) Combined small and medium $P$. monodon injected with GAV 
GAV infection in these survivors and their susceptibility to super-infection with GAV is the subject of ongoing study. When estimated by non-linear regression, the difference between the slopes of mortality curves $(t$-value $=2.40, \mathrm{p}<0.01)$ for $P$. esculentus and P. monodon was marginally significant and the difference between the turning points of the mortality curves $(t$-value $=0.12)$ was not significantly different. This shows that mortalities for these species commenced at the same time, but that significantly fewer $P$. esculentus died. Therefore, $P$. esculentus may be slightly more resistant to the development of overt GAV infection than P. monodon. However, both of these species were far more susceptible to disease than large Marsupenaeus japonicus (Fig. 1b).

Healthy, small to medium Fenneropenaeus merguiensis (average weight $=10.5 \mathrm{~g}$ ) were also investigated for susceptibility to GAV infection. Following experimental GAV infection, F. merguiensis displayed pink colouration of appendages and body surface, lethargy and a lack of appetite by Day 9 p.i. Cumulative mortalities reached $86 \%$ by Day 21 p.i. and remained lower than for Penaeus monodon of the same size (Fig. 2). When estimated by non-linear regression, the slopes $(t$-value $=8.18, \mathrm{p}<0.001)$ and turning points $(t$-value $=$ $4.80, \mathrm{p}<0.001$ ) of the mortality curves for F. merguiensis and P. monodon were significantly different. This indicates that cumulative mortalities for $F$. merguiensis occurred at a slower rate and later in time than for $P$. monodon of the same size. F. merguiensis appears to be more resistant to the development of overt GAV infection than P. monodon. Due to the unavailability of larger animals, the relationship between size and susceptibility to disease was not determined for $F$. merguiensis.

In this study, we show that Penaeus monodon, $P$. esculentus, Marsupenaeus japonicus, and Fenneropenaeus merguiensis are susceptible to GAV infection and develop disease. It has been established previously that GAV from Australia and YHV from Thailand are distinct but closely related viruses (Spann et al. 1997, Cowley et al. 1999). P. monodon is a natural host of both GAV in Australia and YHV in Thailand. Although GAV has not been reported in stocks of $M$. japonicus cultured in Australia, a yellow head-like virus was identified in 1 to $3 \mathrm{~g} \mathrm{M}$. japonicus from Taiwan which were co-infected with white spot syndrome virus (WSSV; Wang et al. 1996). P. monodon stocks from Taiwan have also been shown to be co-infected with YHV and WSSV (Wang \& Chang 2000). F. merguiensis from Thailand has been infected experimentally with YHV, and has been implicated as a carrier of latent YHV infection in prawn culture ponds (Flegel et al. 1996). The susceptibility of $P$. esculentus to infection by YHV is not known. Four penaeid species cultured in the Americas, Farfarntepenaeus aztecus, Farfantepenaeus duorarum (also called Penaeus aztecus and $P$. duorarum), Litopenaeus vannamei and Litopenaeus stylirostris (also called Penaeus vannamei and $P$. stylirostris) are not known to be natural hosts of YHV, but are susceptible when injected with or fed YHVinfected tissue (Lu et al. 1994, Lightner et al. 1998). Metapenaeus ensis, Paleamon styliferus and Euphausia superba have also been reported to be natural hosts of YHV in Thailand (Flegel 1997).

The data presented in this paper also indicate that there are differences in the susceptibility of penaeid species to disease following GAV infection. Penaeus monodon, the natural host, was most susceptible to disease and associated mortality. P. esculentus and Fenneropenaeus merguiensis were marginally less susceptible than P. monodon. In Marsupenaeus japonicus, there was a size-related resistance in which prawns smaller than $12 \mathrm{~g}$ were more likely to develop disease. It is possible that disease may have been delayed in larger M. japonicus. However, there was no significant mortality in 18 to $23 \mathrm{~g}$ prawns at $23 \mathrm{~d}$ postinjection, at which time the cumulative mortalities in small $M$. japonicus and all size classes of $P$. monodon had reached $100 \%$. Although the mechanism of sizerelated resistance to GAV infection in M. japonicus is unknown, subsequent RT-nPCR studies have shown that surviving prawns are infected and appear to remain infected but healthy for several months after inoculation (K.M.S. and colleagues unpubl. data). It appears, therefore, that the mechanism relates to susceptibility to disease rather than to infection per se.

Variations in the susceptibility of penaeid species to viral infection have been described previously. Bell \& Lightner (1984) have shown that infectious hypodermal and haematopoeitic necrosis virus (IHHNV) is more pathogenic in Litopenaeus stylirostris than in Litopenaeus vannamei. Bell \& Lightner (1987) also reported less rapid development of histopathological lesions in larger L. stylirostris infected with IHHNV. Taura syndrome virus (TSV) has been reported to be highly pathogenic for L. vannamei and Fenneropenaeus chinensis (also called Penaeus chinensis), less pathogenic for $L$. stylirostris and Litopenaeus setiferus (also called Penaeus setiferus) and infectious, but nonpathogenic, for F. duorarum and F. aztecus (Brock et al. 1995, Overstreet et al. 1997). Lotz (1997) found no correlation between size and susceptibility of $L$. vannamei to TSV infection.

All 4 penaeid species examined in this study have been farmed commercially in Australia. Penaeus esculentus and Fenneropenaeus merguiensis have been farmed on a relatively small scale to date. However, as they are not natural hosts of GAV, they have been viewed as possible alternative culture species to $P$. 
monodon. The data reported here demonstrate that both species are susceptible to infection by GAV when injected intramuscularly. Other means of infection need to be investigated. However, the results indicate that there is a risk of transmission of GAV when $P$. monodon is cultured in the same vicinity or in polyculture with other penaeid prawns. In Australia, P. monodon and other species are sometimes cultured on the same site and it is common for P. monodon and Marsupenaeus japonicus farms to operate in close proximity and share the same water systems. Care should be taken to avoid cross-contamination with water or moribund animals potentially infected with GAV.

Acknowledgements. Experimental prawns were supplied by Gold Coast Marine Aquaculture Pty. Ltd, Tomei Australia Pty. Ltd and Seafarm Pty. Ltd. The authors thank Mr Eric Boel from the Department of Microbiology and Parasitology, The University of Queensland, for his assistance in capturing Fenneropenaeus merguiensis and Dr Peter Jones, CSIRO Mathematical and Information Sciences, for his assistance with the statistical analyses.

\section{LITERATURE CITED}

Bell TA, Lightner DV (1984) IHHN virus: infectivity and pathogenicity studies in Penaeus stylirostris and Penaeus vannamei. Aquaculture 38:185-194

Bell TA, Lightner DV (1987) IHHNV disease of Penaeus stylirostris: effects of shrimp size on disease expression. J Fish Dis 10:165-170

Boonyaratpalin S, Supamattaya K, Kasornshandra J, Direkbusaracom S, Aekpanithanpong U, Chantanachookin C (1993) Non-occluded baculo-like virus, the causative agent of yellow-head disease in the black tiger shrimp (Penaeus monodon). Gyobyo Kenkyu 28(3):103-109

Brock JA, Gose R, Lightner DV, Hasson K (1995) An overview of Taura syndrome, an important disease of farmed Penaeus vannamei. In: Browdy CL, Hopkins JS (eds) Swimming through troubled waters. Proceedings of the Special Session on Shrimp Farming. World Aquaculture 95. World Aquaculture Society, Baton Rouge, p 84-93

Chantanachookin C, Boonyaratpalin S, Kasornchandra J, Direkbusarkom S, Ekpanithanporn U, Supamataya K, Sriurairatana S, Flegel TW (1993) Histology and ultrastructure reveal a new granulosis-like virus in Penaeus monodon affected by yellow-head disease. Dis Aquat Org $17: 145-157$

Cowley JA, Dimmock CM, Wongteerasupaya C, Boonsaeng V, Panyam S, Walker PJ (1999) Yellow head virus from

Editorial responsibility: Timothy Flegel,

Bangkok, Thailand
Thailand and gill-associated virus from Australian are closely related but distinct viruses. Dis Aquat Org 36: 153-157

Cowley JA, Dimmock CM, Spann KM, Walker PJ (2000a) Gill-associated virus of Penaeus monodon prawns: an invertebrate virus with ORF1a and ORF 1b genes related to arteri- and coronaviruses. J Gen Virol 81:1473-1484

Cowley JA, Dimmock CM, Spann KM, Walker PJ (2000b) Detection of Australian gill-associated virus (GAV) and lymphoid organ virus (LOV) of Penaeus monodon by RTnested PCR. Dis Aquat Org 39:159-167

Flegel TW (1997) Special topic review: major viral diseases of the black tiger prawn (Penaeus monodon) in Thailand. World J Microbiol Biotech 13:433-442

Flegel TW, Boonyaratpalin S, Withyachumnarnkul B (1996) Progress in research on yellow-head virus and white-spot virus in Thailand. World Aquaculture '96, Bangkok, Book of abstracts, World Aquaculture Society, Baton Rouge, p 126

Lightner DV, Hasson KW, White BL, Redman RM (1998) Experimental infection of western hemisphere penaeid shrimp with Asian white spot syndrome virus and Asian yellow head virus. J Aquat Anim Health 10:271-281

Lotz JM (1997) Effect of host size on virulence of Taura virus to the marine shrimp Penaeus vannamei (Crustacea: Penaeidae). Dis Aquat Org 30:45-51

Lu Y, Tapay LM, Brock JA, Loh PC (1994) Infection of the yellow head baculo-like virus (YBV) in two species of penaeid shrimp, Penaeus stylirostris (Stimpson) and Penaeus vannamei (Boone). J Fish Dis 17(6):649-656

Overstreet RM, Lightner DV, Hasson KW, McIlwain S, Lotz JM (1997) Susceptibility to Taura syndrome virus of some penaeid shrimp species native to the Gulf of Mexico and the southeastern United States. J Invertebr Pathol 69: $165-176$

Paterson WD, Stewart JE (1974) In vitro phagocytosis by hemocytes of American lobster (Homarus americanus). J Fish Res Board Can 31:1051-1056

Pérez-Farfante I, Kensley B (1997) Penaeoid and sergestoid shrimps and prawns of the world. Keys and diagnoses for the families and genera. Mémoires du Muséum National D'Histoire Naturelle 175, Paris

Spann KM, Vickers JE, Lester RJG (1995) Lymphoid organ virus of Penaeus monodon from Australia. Dis Aquat Org 23:127-134

Spann KM, Cowley JA, Walker PJ, Lester RJG (1997) A yellow-head-like virus from Penaeus monodon cultured in Australia. Dis Aquat Org 31:169-179

Wang CS, Tang KFJ, Kou GH, Chen SN (1996) Yellow head disease-like virus infection in the Kuruma shrimp Penaeus japonicus cultured in Taiwan. Fish Pathol 31(4):177-182

Wang YC, Chang PS (2000) Yellow head virus infection in the giant tiger prawn Penaeus monodon cultured in Taiwan. Fish Pathol 35:1-10

Submitted: July 16, 1999; Accepted: July 10, 2000 Proofs received from author(s): September 11, 2000 